\title{
Årsbokstankar vid ett tioårsjubileum
}

\author{
Av Jan Lindroth
}

1.

Vad skall en idrottshistorisk årsbok syssla med? Vilka målgrupper är det rimligt att vända sig till, hur bör innehållet utformas $\mathrm{i}$ det vida fältet mellan vetenskapligt och populärt, vad finns att säga om redaktionell sammansättning, om medarbetarna, om illustrationer och om den yttre gestaltningen? Frågorna är många, svaren på intet sätt givna. För alla som är engagerade $i$ årsskriftsarbete är det angeläget att vara öppen för diskussion och därigenom ompröva den löpande publicering som annars lätt hamnar i slentrian.

I praktiken infinner sig ofta de allmänna funderingarna i jubileumstider. I maj 1994 firade $\gg$ Dansk Idrætshistorisk forening krop og kultur « tio år med ett rikhaltigt komponerat och mycket vällyckat heldagsmöte på Danmarks Højskole for Legems$\varnothing$ velser. Intet ont anande accepterade jag tacksamt en vänlig invitation att som gäst från en äldre systerorganisation (Svenska idrottshistoriska föreningen, stiftad 1976) muntligt föredro några synpunkter på föreningen i allmänhet och dess årsbok i synnerhet. Den aning som borde ha infunnit sig var att en påpasslig årsboksredaktion givetvis senare skulle höra av sig med önskemål om något skriftligt. Så har skett och här kommer några strödda årsbokstankar.

\section{2.}

Dessa rader läses i den tionde årsboken. De nio tidigare publicerade innehåller enligt min additionskonst 1654 trycksidor. Det är en betydande produktion av idrottshistorisk text. Vi har uppenbarligen att göra med en etablerad skriftserie i årsboksform. Vad vittnar den om? I stort vågar man svara att den är ett gott tecken på erkännande av idrottshistoria som ett både berättigat och etablerat fenomen i idrotts-, kultur- och forskarvärlden. Årsbokssviten är i sig själv en källa, närmare bestämt en fysisk kvarleva av den märkligt senfärdiga, internationella utveckling som äntligen promoverat idrottshistorian till ett angeläget kunskapsoch forskningsområde. Det är glädjande och bådar gott för framtiden.

Vilka förutsättningar har en idrottshistorisk årsbok att bli om inte en »best-seller« så dock en anständigt utbredd publikation? I förstone kan man lätt få för sig att förutsättningarna är utmärkta. Den har nyhetens behag, både idrotts- och historieintresset är väl spridda och det finns mycket spännande att skriva om. Men erfarenheterna talar ett bistrare språk; såvitt bekant saknas exempel på masspridning inom gebitet.

Varför har den danska årsboken, liksom den svenska och även andra, så pass begränsad avsättning? En deprimerande orsak skulle kunna vara att de är dåliga. Men så 
är inte fallet, i varje fall inte med den danska. Jag tror att vi har att göra med två huvudorsaker.

Den ena gäller idrotten som intresseområde. Detta område är alltför stort, det täcker ett väldigt fält av etablerade idrottsgrenar och fysiska aktivitetstyper alltifrån den elitistiska världsidrottens yppersta artisteri via den enkla division 3-matchen i fotboll till den ensamma och privata joggingrundan nära det egna hemmet. Därmed vänder sig en allmän skrift om idrott till både alla och ingen. De flesta har sina specialintressen.

Tesen är med andra ord att ett snävare intresseområde inom idrotten kunde appellera mera. Det skulle vara lättare att locka med en årlig publikation om idrottshistoria i Köpenhamn eller Århus, om fotboll eller cykel för att inte tala om golf eller tennis. Svenska exempel tyder på detta. De visar även att årsböcker om en enstaka författare, exempelvis Selma Lagerlöf eller Albert Engström, kan nå över tusen fasta läsare. Sådana författare i all ära, inte kan de i betydelse jämföras med idrotten som helhet men de har styrkan att representera något tydligt, väl avgränsat och attraktivt.

Den andra orsaken sammanhänger med de allmänna förväntningarna på vad idrott är och bör vara. Det gäller förväntningar bland både idrottsintresserade och kulturoch historieintresserade. De idrottsintresserade förknippar idrott med rafflande, dagsaktuellt artisteri, tävlingar av lägre dignitet eller motion. Det är något som händer i nuet, en färskvara för omedelbar konsumtion. Däremot är det inget man skall grubbla djupare på eller läsa om i historieböcker - skolundervisningen har underbyggt föreställningen om historia som något väsensskilt från vanligt folks vardag, fritid och nöjen. Kulturfolket å sin sida har ofta distanserat sig från idrotten. Möjligen låter man sig ryckas med av tävlingarna men det går sällan så långt att man seriöst vill tillägna sig den bakgrund och djupare förståelse idrottshistorikerna erbjuder.

Oavsett den faktiska spridningen av idrottshistoriska årsböcker kan man fråga sig vilka målgrupper som $\mathrm{i}$ första hand bör väljas. Själv har jag erfarenheten att idrottsledare är den grupp som har den största potentialen. De är i regel ideellt inställda, betalar gärna en mindre årlig summa pengar för medlemskap/prenumeration och uppskattar att läsa om den verksamhet de själva tagit del i. Gymnastik- och idrottslärare liksom sportjournalister, det vill säga de två mest frekventa idrottsliga yrkeskårerna (vid sidan av aktiva ickeamatörer?), är svårare att locka. Forskare och andra akademiker kan värvas men blir trots allt inte många. Kulturinstitutioner med allsidiga ambitioner är en tacksam grupp - men begränsad.

Frågan om målgrupper leder in på idrottshistoriska årsböckers utformning och innehåll. Bedömningen blir givetvis olika beroende på vilken målgrupp man $\mathrm{i}$ första hand vänder sig till. Idrottsledare önskar ett innehåll, forskare ett annat. Man kan som exempel på skilda värderingar ta frågan om illustrationer. För forskaren är sådana i underhållande syfte umbärliga, för idrottsledarna närmast nödvändiga. Den högvetenskapliga årsboken skulle mycket väl klara sig utan illustrationer, men inte den som vänder sig till en bredare publik.

Valet mellan en strikt vetenskaplig och en populär inriktning är inte helt enkelt. Det behövs enligt min mening inslag av båda alternativen för att ge rimliga förutsättningar för en anständigt stor läsekrets och bidrag från forskningsorgan. Frågan är därför inte antingen-eller utan hur blandningen skall se ut. Här kan man tänka sig dels att ha en enhetsblandning i varje arti- 
$\mathrm{kel} / \mathrm{inslag}$, dels att låta vissa vara strikt vetenskapliga, andra genomgående populära (ovetenskapliga). Alternativen kan låta konstruerade men innehåller en påträngande realitet.

Det mesta talar även här för en blandform. Det innebär alltså att vissa inslag är strikt vetenskapliga, andra lika renodlat populära, medan ytterligare andra ligger mitt emellan. Med sådan flexibilitet kan både den hyperseriösa forskaren och den intresserade amatören ha något att hämta i årsboken, kanske också själv medarbeta i den. Man får med en sådan strategi även in vetenskapligt tungviktiga originalartiklar, som gör det berättigat att söka forskningsanslag för årsboken och inlämmar den som ett värdefullt inslag i den litteratur som representerar forskningsfronten.

Ytterligare ett par frågor av allmän natur gäller innebörden av begreppet idrottshistoria. Måste en årsbok inom detta gebit vara just historisk eller bör den utvidgas till att omfatta hela det humanistiska och kulturella fältet? Mera konkret uttryckt: hör filosofi, språkvetenskap, etnologi och andra discipliner utan given historisk inriktning till det intresseområde som skall täckas? Och hur ställa sig till idrottens kulturminnesvårdande aspekter, till arkiv, bibliotek/ litteratur och museer och idrottslivets övriga efterlämnade föremål (idrottsplatser, utrustning, priser och andra prylar)?

3.

Det är hög tid att gå i närkamp med den danska årsboken, att göra ett försök till karakterisering, antyda styrka och svaghet. Tyngdpunkten läggs på textinnehållet och vad det säger om dansk idrottshistorisk forskning. Men först några punkter utanför den ramen.

Vad beträffar det redaktionella arbetet är strategin tydligen att arbeta med ambulerande redaktioner. Det ter sig mycket tilltalande och passar givetvis särskilt väl i samband med temanummer. Med denna lösning kommer man ifrån två alternativ med uppenbara nackdelar: dels den stående redaktionskommittén som omger en ansvarig huvudredaktör och som tenderar att försjunka i passivitet, dels den snart utslitna ensamredaktören.

Medarbetarstaben är grundläggande för en god årsbok. Den kan bland annat bedömas utifrån polerna pluralism - ensidighet. I praktiken sammanhänger den aspekten nästan ofrånkomligen med numerären. Många medarbetare ger normalt mångfald och omväxling, få leder till motsatsen. Jag har inte gjort någon statistik exempelvis på det genomsnittliga antalet medarbetare i årsböckerna, än mindre räknat ut det totala antalet. Redan en flyktig okulärbesiktning av innehållsförteckningarna visar övertygande att medarbetarstaben är stor och tämligen brokigt sammansätt. Redaktionerna har lyckats väl i sin strävan att mobilisera många skrivkunniga medarbetare med något väsentligt att presentera.

Detta är emellertid inte hela sanningen. Man kan urskilja ett »järngäng « (konsekvent undviker jag personnamn i denna artikel), som troget återkommer med bidrag. Det antyder att reservoaren av medarbetare inte är oändlig. Enstaka bidrag ger intryck av att vara tillkomna mer av redaktionell plikt än av ohejdbar skrivlusta med bakomliggande studie- och forskningsarbete, som pockar på publicering.

Illustrationerna har blivit allt bättre. Till en början (1985-86) ser man att de inte var högprioriterade. En omprövning har uppenbarligen därefter skett. Samma utveckling har för övrigt gått igen i den svenska idrottshistoriska årsboken (Idrott, historia och samhälle, startad 1981). Den började 
bildlös, men kapitulerade inför ett yttre tryck från och med sin fjärde utgåva. För egen del intar jag i illustrationsfrågan en -hopplös minoritetsposition genom att egentligen föredra uteslutande ren text och acceptera illustrationer endast som källmaterial, alltså för att öka den seriösa förståelsen av texten, inte som allmän underhållning. En sådan inställning kolliderar givetvis med strävan att ge årsboken en populär framtoning och är - det måste erkännas - i grund och botten orealistisk.

En annan fråga gäller bevakningen av idrottshistorisk litteratur. Att någon sådan bevakning bör ske framstår som en självklarhet - men hur skall den materialiseras? Mest ambitiöst är det givetvis att arbeta med utförliga, vetenskapliga recensioner av viktigare verk, det vill säga flera sidors ingående granskning av vart och ett med väl underbyggd negativ och positiv kritik. Nackdelen är att sådana recensioner fordrar betydande utrymme, kräver åtskilligt arbete av recensenten och i första hand intresserar specialisterna. $\AA$ andra sidan kan man fråga sig var sådana recensioner annars skall publiceras, ty det står klart att de behövs. Den danska årsboken har på senare tid använt sig av översiktliga litteraturorienteringar och bibliografier, vilket är utmärkt. Men enstaka omfattande recensioner kanske kunde beredas plats vid sidan av översikterna.

Vad beträffar greppet på ämnet kan det utan tvekan karakteriseras som mycket brett. Den första årsboken anger tonen. Här serveras ett allsidigt smörgåsbord med inslag om metod och historiografi, socialhistoria, gymnastik, idrott och politik, idrottshistoria i kulturminnesvården, skola och fysisk aktivitet i nuet. Även årsbok nummer två representerar en uppvisning $\mathrm{i}$ mångsidighet. Därefter dominerar tematiska årsböcker, vilket inte utesluter breda grepp, men ändrar förutsättningarna.
Det breda greppet förvånar inte och symboliseras av föreningsnamnets senare del: krop og kultur. Man nöjer sig med andra ord inte med idrottshistoria i snäv mening. Även idrottskulturen i allmännare mening ingår inklusive frågor av mer dagsaktuell än historisk prägel (möjligheterna att kombinera historia och nutid är givetvis goda). Det betyder att även de kulturminnesvårdande aspekterna tillgodoses (dock måste jag efter en kvartssekellång tjänstgöring $\mathrm{i}$ Riksarkivet i Stockholm beklaga att idrottsarkiven något försummas både $\mathrm{i}$ årsboken och på andra sätt).

Det breda greppet är i det stora hela en styrka. Men drivet till sin spets kan det möjligen skapa osäkerhet om var gränserna går. Den som är lagd för väl utstakade revir önskar större tydlighet. Kroppskultur är ju något mycket vidsträcktare än idrott. Skall en idrottshistorisk årsbok även syssla med kosmetologi, sjukgymnastik och hälsobefrämjande profylax, renhållning av kroppen, soldyrkan och badliv? För egen del tycker jag nog att ett moment av fysisk aktivitet, av människan i rörelse (homo movens) är det centrala, medan en ohämmad expansion till kroppskultur i allmänhet och än mer till kroppshistoria (inklusive arbetsliv, sjukdomar/medicinhistoria $\mathrm{mm}$ ) leder alltför långt. Till saken hör att den danska årsboken $\mathrm{i}$ huvudsak tillfredsställer den restriktiva linjen.

Systemet med temanummer har både för- och nackdelar. Årsboken har i temaform behandlat ämnen som gymnastik, ledning och utbildning inom idrotten och olympismen. Det är tydliga områden, väl lämpade för en koncentrerad presentation. Man făr här en värdefull genomlysning av ett aktuellt område. Nackdelen är ofrånkomlig och kan exempelvis innebära att gymnastikhataren (sådana finns nog även i Danmark) får en överflödig årsbok - men 
med en inbyggd förhoppning om bättre lycka nästa gång.

Mer betänksam kan man bli inför stora, vagt formulerade temata som $» k r o p s k u l t u r$ og Idræt - regionalt, nationalt og internationalt«. Man känner igen samma problematik vid internationella kongresser, där organisatören pendlat mellan den snäva avgränsningens Scylla och den välvilliga allomfattningens Charybdis. Kunde det inte i sådana fall vara lika bra att avstå från fiktionen av temanummer och markera att full ämnesfrihet föreligger?

Som en avslutande allmän punkt till årsbokskarakteristiken vill jag peka på det essäistiska draget i publicerade artiklar och uppsatser. Det är ett drag som generellt utmärker dansk humanistisk litteratur i jämförelse med exempelvis den svenska. Skillnaden framträder tydligt inom kärnämnet historia, där vi i norr har ett betydligt stramare framställningssätt. I stället för språklig elegans, vidsträckt beläsenhet och utrymme för fria associationer dominerar tydliga frågeställningar och resultatredovisningar, energisk närkamp med tryckt och otryckt källmaterial och snäva ämnesramar. Det skulle bli alltför vidlyftigt att här diskutera för och nackdelar med de olika riktningarna. Önskemålet för framtiden är givet: att vi influeras av varandra och därmed blir allsidigare.

\section{4.}

I vilken utsträckning speglar de nio årsböckerna dansk idrottshistorisk forskning i allmänhet? Det finns anledning att räkna med att spegeleffekten $\mathrm{i}$ det stora hela är god. Studier och intresseområden sätter direkt eller indirekt sina spår i årsboken genom en automatisk process, med en bidragssökande redaktion som primus motor. En ambitiös redogörelse över denna forskning skulle givetvis fordra att monografier och andra skrifter utanför årsboksramen beaktades. Dessutom behövdes stort textutrymme. Här nöjer jag mig med några isolerade iakttagelser, inte utan subjektiv prägel.

Gymnastiken har intresserat årsboken i hög grad. Det har givetvis fătt ett temanummer men även dragit till sig uppmärksamhet på andra sätt. Detta stämmer väl med i övrigt kända förhållanden inom dansk idrottshistorisk forskning. Ett skäl är som bekant linggymnastikens introduktion på den danska landsbygden under 1880-talet och dess roll i en kulturell kamp mellan land och stad och i en politisk kamp mellan venstre och höjre. Detta gymnastikhistoriska intresse är inspirerande för svenska kolleger med märkbara svårigheter att initiera den forskning kring linggymnastikens utveckling som är så angelägen och som legat nere sedan mitten av 1900-talet.

I fråga om idrottsrörelsen, det vill säga i huvudsak den i frivilliga föreningar organiserade tävlingsidrotten, är förhållandena omvända. Med den är vi inne på det moderna (sportifierade) idrottslivet med centrum i urbana miljöer. Här har svensk forskning med viss ensidighet satt in sina stötar, medan man i Danmark gått runt detta tema som katten kring het gröt. Det är nog ingen tvekan om att skillnaden delvis kan föras tillbaka på forskarnas personliga rancuner och faiblesser - ett i längden otillfredsställande förhållande.

Årsböckerna återspeglar visserligen sammanlagt en hel del stoff med anknytning till den danska idrottsrörelsen. Men hur det stora och pluralistiska idrottsorganisatoriska komplexet i Danmark uppstått och utvecklats över en längre tidsaxel vet vi inte mycket om genom nyare forskning. Därför finns det en risk att smärre delstudier blir hängande i luften. Man har hittills 
föredragit att gå rakt på idrottens manifestationer, inte om- eller genvägen över organisationerna.

Att döma bland annat av den senaste årsboken finns det nu tecken på att man $\mathrm{i}$ dansk forskning håller på att i stor skala ta sig an den egna idrottsrörelsen och beakta inte minst den organisatoriska utvecklingen. Utlösande faktor är tydligen Danmarks Idræts-Forbunds 100-årsjubileum 1996, som initierat ett brett upplagt historiskt projekt. Man vågar väl anta att detta framdeles kommer att återspeglas i årsboken, som ännu inte haft något temanummer med sådan inriktning.

Inom kärnämnet historia spelar traditionellt den politiska, sociala och ekonomiska samhällsutvecklingen huvudrollen vid val av ämnen och forskningssatsningar. I varje fall gäller detta i Sverige. Senare har visserligen nya inriktningar gjort sig gällande, men utan att eliminera de traditionella tyngdpunkterna. Det är då en intressant iakttagelse att den danska årsbokssviten i så pass liten utsträckning ger sig i kast med idrottslivet (i vid mening) utifrån dessa centrala infallsvinklar. Här finns stora expansionsområden, som för övrigt hänger naturligt samman med folkrörelse- och organisationskomplexet.

I högre grad återspeglar årsböckerna ett kulturanalytiskt angreppssätt, där idrotten studeras som kulturfenomen i relation till sin omvärld och där den idrottande kroppen framstår som ett källmaterial med betydelsefullt innehåll värt att analysera och förklara. Denna iakttagelse kan ses som uttryck för att man i Danmark står kroppen närmare än vad berörda forskare gör i exempelvis Sverige. I flera bidrag framgår en förståelse för kroppsrörelse, som förutsätter en avancerad förförståelse. Bilden får därvid större betydelse. Vad beror skillnaden på? En förklaring skymtar. Danska idrottshistoriker har ganska ofta en gymnastik- och idrottslärarutbildning och står i övrigt den levande idrottspedagogiken närmare än sina mer teoretiskt-humanistiskt och därmed ensidigt utbildade nordiska kolleger?

Ett drag gemensamt för många av årsboksbidragen är den internationella orienteringen, ett område där Danmark gått $\mathrm{i}$ spetsen bland de nordiska länderna. Internationalismen märks på två sätt. Dels väljs ämnen med icke-dansk inriktning, något som ger sig till känna redan i början av sviten och som kulminerar exempelvis i temanumret om olympismen. Dels utgår man inte sällan vid ämnen med dansk tematik från den internationella forskningen, som tidigt introducerades i Danmark. Parallellt med detta kan man spåra ett teoretiskt intresse, som först på senaste tid fătt motsvarigheter på andra håll i Norden.

5.

Det återstår att avsluta med några lika enkla som välmenade önskemål. Det första och viktigaste är att årsboken; som nu nått sitt första tiotal, kommer att florera många decennier ytterligare med i det stora hela samma program som hittills.

Ett par önskemål i lätt modifierande riktning gäller vetenskapligheten. Jag tror på nyttan av ett mindre antal (1-3) uppsatser i varje årsbok med full vetenskaplig tyngd och ornamentering för att befästa positionen i en krävande forskarvärld, motivera forskningsanslag och stimulera ny forskning eller publicering av äldre. I samma anda kan man efterlysa ett mindre antal vetenskapligt fullfjädrade recensioner.

Denna skärpning av vetenskapligheten kan med fördel kombineras med en lika målmedveten satsning på populära inslag, kanske med mer inriktning på debatt och 
dagsaktualitet. Det gäller dock att hålla isär de två. Lösenordet blir renodling. Önskemålet aktualiserar frågan om idrottshistoria som bottenplatta för en humanistiskt fotad idédiskussion om idrottens utveckling förr, nu och i framtiden.

Ett önskemål där subjektivismen kanske frodas över måttan gäller arkiven. Man riskerar visserligen att smutsa ner sina fingrar vid intensivare arkivforskning - men det är reparabelt, utbytet blir ofta gott och en förutsättning för fullödig forskning. Därtill kan »fynd « göras, som förtjänar årsbokspublicering. Kort sagt ligger enligt årsbokens vittnesbörd Danmark på efterkälken inom arkivforskningen, vilket lätt kan ändras om viljan finns.

Slutligen önskas Idrætshistorisk årbog en vidare spridning - det är den värd och det ligger inom möjligheternas gräns. 
